\title{
IgE-Mediated Hypersensitivity and Desensitisation with Recombinant Enzymes in Pompe Disease and Type I and Type VI Mucopolysaccharidosis
}

\author{
Murat Capanoglu ${ }^{a}$ Emine Dibek Misirlioglu ${ }^{a}$ Dilek Azkur ${ }^{a}$ Emine Vezira \\ Hakan Guvenir $^{\mathrm{a}}$ Mehmet Gunduz ${ }^{\mathrm{b}}$ Muge Toyran ${ }^{\mathrm{a}}$ Ersoy Civelek ${ }^{\mathrm{a}}$ \\ Can Naci Kocabasa, c

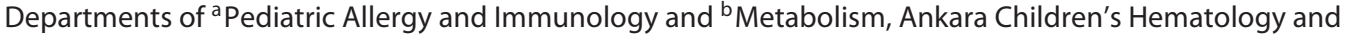 \\ Oncology Hospital, Ankara, and 'Department of Pediatric Allergy, Faculty of Medicine, Mugla Sitki Kocman \\ University, Mugla, Turkey
}

\section{Established Facts}

- Enzyme replacement therapy (ERT) is important in reducing the morbidity and mortality rates of lysosomal storage disorders.

- Reactions can be experienced during ERT caused by either IgE-mediated or non-immunologic mechanisms.

- When slowing the rate of infusion and/or premedication fail to prevent reactions, desensitisation is indicated.

\section{Novel Insights}

- In the literature, there are only a few reports on patients who experienced hypersensitivity reactions to different ERTs, underwent enzyme desensitisation and were able to continue with treatment.

\section{Key Words}

Alglucosidase alfa · Arylsulfatase B · Desensitization · Hypersensitivity reaction - Laronidase . Mucopolysaccharidosis - Metabolic disorders · Pompe disease

\begin{abstract}
Enzyme replacement therapy (ERT) is important for the treatment of lysosomal storage disorders. Hypersensitivity reactions with ERT have been reported, and in these cases, desensitisation with the enzyme is necessary. Here we report the cases of 3 patients with lysosomal storage disorders, including Pompe disease and mucopolysaccharidosis type I
\end{abstract}

\section{KARGER}

E-Mail karger@karger.com www.karger.com/iaa (c) 2016 S. Karger AG, Base

$1018-2438 / 16 / 1693-0198 \$ 39.50 / 0$

Correspondence to: Prof. Dr. Can Naci Kocabas

Department of Pediatric Allergy and Immunology

Ankara Children's Hematology and Oncology Hospital

TR-06110 Ankara (Turkey)

E-Mail cankocabas@yahoo.com 
and VI, who had IgE-mediated hypersensitivity reactions and positive skin tests. Successful desensitisation protocols with the culprit enzyme solution were used for these patients. All 3 patients were able to safely receive ERT with the desensitisation protocol.

(C) 2016 S. Karger AG, Basel

\section{Introduction}

Congenital metabolic disorders result from the absence or abnormality of an enzyme or its cofactor, leading to either the accumulation or deficiency of a specific metabolite [1]. Lysosomal storage disorders are caused by defective lysosomal metabolism, which leads to the accumulation of various glycosaminoglycans, glycoproteins or glycolipids in the lysosomes of various tissues [2]. Enzyme replacement therapy (ERT) is vital for the treatment of lysosomal storage disorders, including Pompe disease, mucopolysaccharidosis type I (MPS I) and MPS VI. It is generally safe and well-tolerated, but hypersensitivity reactions (rash, urticaria, angioedema, bronchoconstriction, rhinitis and anaphylaxis) in response to ERT have been reported. However, these reactions are usually mild or moderate [3-5].

In the absence of alternatives, such patients require long-term ERT, even if they exhibit hypersensitivity reactions. Therefore, desensitisation with the culprit recombinant enzyme may be essential. Here, we report the cases of 3 patients with lysosomal storage disorders who experienced IgE-mediated hypersensitivity reactions in response to ERT and had positive skin tests with a culprit enzyme (alglucosidase alfa, arylsulfatase B and laronidase) solution. Each patient received the culprit enzyme according to different successful desensitisation protocols designed for each enzyme.

\section{Case Report}

Case 1

A 17-month-old girl was diagnosed with Pompe disease during the neonatal period; her brother had previously died from Pompe disease. She had been receiving alglucosidase alfa (Myozyme ${ }^{\circledR}$ ) ERT $(20 \mathrm{mg} / \mathrm{kg}$ ) every 2 weeks since birth. When she was 4 months old, at the eighth dose of ERT, she experienced urticaria on her face and trunk, without systemic symptoms, 60 min after starting the procedure. The infusion was stopped, and the patient was treated with $0.5 \mathrm{mg} / \mathrm{kg}$ of hydroxyzine. The symptoms improved $1 \mathrm{~h}$ later and the infusion was restarted. After $10 \mathrm{~min}$, she experienced generalised urticaria again, and so the infusion was discontinued. Two weeks after the reaction, the patient was intravenously premedi-
Table 1. Protocol for intravenous desensitisation with alglucosidase alfa

\begin{tabular}{rrrrlrr}
\hline $\begin{array}{c}\text { Step Solution, } \\
\mu \mathrm{g} / \mathrm{ml}\end{array}$ & \multicolumn{2}{c}{$\begin{array}{l}\text { Amount, Rate, } \\
\mathrm{ml}\end{array}$} & $\begin{array}{l}\text { Time, } \\
\mathrm{ml} / \mathrm{h} \text { Dose, } \\
\mu \mathrm{g}\end{array}$ & $\begin{array}{l}\text { Cumulative } \\
\text { dose, } \mu \mathrm{g}\end{array}$ \\
\hline 1 & $0.1(\mathrm{~A})$ & 5 & 15 & 20 & 0.5 & 0.5 \\
2 & $0.1(\mathrm{~A})$ & 15 & 45 & 20 & 1.5 & 2 \\
3 & $1(\mathrm{~B})$ & 5 & 15 & 20 & 5 & 7 \\
4 & $1(\mathrm{~B})$ & 15 & 45 & 20 & 15 & 22 \\
5 & $10(\mathrm{C})$ & 5 & 15 & 20 & 50 & 72 \\
6 & $10(\mathrm{C})$ & 15 & 45 & 20 & 150 & 222 \\
7 & $100(\mathrm{D})$ & 5 & 10 & 30 & 500 & 722 \\
8 & $100(\mathrm{D})$ & 15 & 30 & 30 & 1,500 & 2,222 \\
9 & $100(\mathrm{D})$ & 30 & 60 & 30 & 3,000 & 5,222 \\
10 & $1,000(\mathrm{E})$ & 5 & 10 & 30 & 5,000 & 10,222 \\
11 & $1,000(\mathrm{E})$ & 10 & 20 & 30 & 10,000 & 20,222 \\
12 & $1,000(\mathrm{E})$ & 20 & 40 & 30 & 20,000 & 40,222 \\
13 & $1,000(\mathrm{E})$ & 40 & 80 & 30 & 40,000 & 80,222 \\
14 & $1,000(\mathrm{E})$ & 70 & 140 & 30 & 70,000 & 150,000 \\
\hline
\end{tabular}

Target dose: $150 \mathrm{mg}$ of alglucosidase alfa. Total time: $360 \mathrm{~min}$. Solution E (1,000 $\mu \mathrm{g} / \mathrm{ml}): 150 \mathrm{mg}$ of alglucosidase alfa in $150 \mathrm{ml}$ of normal saline solution (SS). Solution D $(100 \mu \mathrm{g} / \mathrm{ml}): 50 \mathrm{ml}$ of SS followed by $5.5 \mathrm{ml}$ of solution E. Solution C $(10 \mu \mathrm{g} / \mathrm{ml}): 27 \mathrm{ml}$ of SS followed by $3 \mathrm{ml}$ of solution D. Solution B $(1 \mu \mathrm{g} / \mathrm{ml}): 27 \mathrm{ml}$ of SS followed by $3 \mathrm{ml}$ of solution C. Solution A $(0.1 \mu \mathrm{g} / \mathrm{ml}): 27 \mathrm{ml}$ of SS followed by $3 \mathrm{ml}$ of solution $\mathrm{B}$.

cated with $1 \mathrm{mg} / \mathrm{kg}$ of diphenhydramine and methylprednisolone $1 \mathrm{~h}$ before the ERT infusion and the infusion rate was decreased. However, she experienced generalised urticaria again. The infusion was interrupted. When she was referred to our clinic, skin tests were performed with alglucosidase alfa [6]. A skin prick test with an undiluted enzyme and an intradermal test with a 1:1,000 dilution were negative. However, an intradermal test with a 1:100 dilution was positive with a $3 \times 3 \mathrm{~mm}$ wheal and flare compared to the control. A 14-step alglucosidase alfa desensitisation protocol using 5 solutions with concentrations starting from 1/10,000 was used, resembling a protocol previously reported in the literature [6] (table 1). Since then, she has been receiving ERT with desensitisation every 2 weeks without any reaction.

Case 2

A 5-year-old boy with MPS VI had been receiving recombinant human arylsulfatase B (Naglazyme ${ }^{\circledR}$ ) weekly since he was diagnosed at the age of 1 year. While receiving ERT at the age of 4 years, he experienced generalised urticaria without systemic symptoms, $30 \mathrm{~min}$ after starting the procedure. The infusion was stopped, and the patient was treated with $0.5 \mathrm{mg} / \mathrm{kg}$ of hydroxyzine. The following week, he was intravenously premedicated with diphenhydramine $(1 \mathrm{mg} / \mathrm{kg})$ and methylprednisolone $1 \mathrm{~h}$ before ERT and the infusion rate was decreased. However, he experienced generalised urticaria again $60 \mathrm{~min}$ after starting the procedure. The infusion was interrupted, and he was referred to our clinic. Skin prick tests with both undiluted and a 1:10 dilution of arylsulfatase B and an intradermal test with a 1:100 dilution were negative. However, an 
Table 2. Protocol for intravenous desensitisation with arylsulfatase B

\begin{tabular}{rllrlrr}
\hline Step & $\begin{array}{l}\text { Solution, } \\
\mu \mathrm{g} / \mathrm{ml}\end{array}$ & \multicolumn{2}{c}{$\begin{array}{l}\text { Amount, Rate, } \\
\mathrm{ml}\end{array}$} & $\begin{array}{l}\text { Time, Dose, } \\
\mathrm{min} / \mathrm{h}\end{array}$ & $\begin{array}{l}\text { Cumulative } \\
\text { dose, } \mu \mathrm{g}\end{array}$ \\
\hline 1 & $7.5(\mathrm{~A})$ & 0.5 & 2 & 15 & 3.77 & 3.7 \\
2 & $7.5(\mathrm{~A})$ & 1 & 4 & 15 & 7.5 & 11.2 \\
3 & $7.5(\mathrm{~A})$ & 2 & 8 & 15 & 15 & 26.2 \\
4 & $7.5(\mathrm{~A})$ & 4 & 16 & 15 & 30 & 56.2 \\
5 & $7.5(\mathrm{~A})$ & 8 & 32 & 15 & 60 & 116.2 \\
6 & $7.5(\mathrm{~A})$ & 16 & 64 & 15 & 120 & 236.2 \\
7 & $150(\mathrm{~B})$ & 1.5 & 6 & 15 & 225 & 461.2 \\
8 & $150(\mathrm{~B})$ & 3 & 12 & 15 & 450 & 911.2 \\
9 & $150(\mathrm{~B})$ & 6 & 24 & 15 & 900 & $1,811.2$ \\
10 & $150(\mathrm{~B})$ & 12.5 & 50 & 15 & 1,875 & $3,686.2$ \\
11 & $150(\mathrm{~B})$ & 25 & 100 & 15 & 3,750 & $7,436.2$ \\
12 & $150(\mathrm{~B})$ & 50 & 200 & 15 & 7,500 & $14,936.2$ \\
\hline
\end{tabular}

Target dose: $15 \mathrm{mg}$ of arylsulfatase B. Total time: $180 \mathrm{~min}$. Solution B $(150 \mu \mathrm{g} / \mathrm{ml}): 15 \mathrm{mg}(15 \mathrm{ml})$ of arylsulfatase B in $85 \mathrm{ml}$ of normal saline solution (SS). Solution A $(7.5 \mu \mathrm{g} / \mathrm{ml})$ : $38 \mathrm{ml}$ of SS followed by $2 \mathrm{ml}$ of solution $\mathrm{B}$.

Table 3. Protocol for intravenous desensitisation with laronidase

\begin{tabular}{rlccccr}
\hline Step & $\begin{array}{l}\text { Solution, } \\
\mu \mathrm{g} / \mathrm{ml}\end{array}$ & $\begin{array}{l}\text { Amount, Rate, } \\
\mathrm{ml}\end{array}$ & $\begin{array}{l}\text { Time, } \\
\mathrm{ml} / \mathrm{h}\end{array}$ & $\begin{array}{l}\text { Dose, } \\
\mu \mathrm{g}\end{array}$ & $\begin{array}{l}\text { Cumulative } \\
\text { dose, } \mu \mathrm{g}\end{array}$ \\
\hline 1 & $0.02(\mathrm{~A})$ & 0.6 & 2.5 & 15 & 0.012 & 0.012 \\
2 & $0.02(\mathrm{~A})$ & 1.2 & 5 & 15 & 0.024 & 0.036 \\
3 & $0.02(\mathrm{~A})$ & 2.5 & 10 & 15 & 0.05 & 0.086 \\
4 & $0.02(\mathrm{~A})$ & 5 & 20 & 15 & 0.1 & 0.186 \\
5 & $0.2(\mathrm{~B})$ & 0.6 & 2.5 & 15 & 0.12 & 0.306 \\
6 & $0.2(\mathrm{~B})$ & 1.2 & 5 & 15 & 0.24 & 0.546 \\
7 & $0.2(\mathrm{~B})$ & 2.5 & 10 & 15 & 0.5 & 1.046 \\
8 & $0.2(\mathrm{~B})$ & 5 & 20 & 15 & 1 & 2.046 \\
9 & $2(\mathrm{C})$ & 1.2 & 5 & 15 & 2.4 & 4.446 \\
10 & $2(\mathrm{C})$ & 2.5 & 10 & 15 & 5 & 9.446 \\
11 & $2(\mathrm{C})$ & 5 & 20 & 15 & 10 & 19.446 \\
12 & $2(\mathrm{C})$ & 10 & 40 & 15 & 20 & 39.446 \\
13 & $20(\mathrm{D})$ & 2.5 & 10 & 15 & 50 & 89.446 \\
14 & $20(\mathrm{D})$ & 5 & 20 & 15 & 100 & 189.446 \\
15 & $20(\mathrm{D})$ & 10 & 40 & 15 & 200 & 389.446 \\
16 & $20(\mathrm{D})$ & 270 & 80 & 200 & 5,400 & $5,789.446$ \\
\hline
\end{tabular}

Target dose: $5.8 \mathrm{mg}$ of laronidase. Total time: $425 \mathrm{~min}$. Solution $\mathrm{D}(20 \mu \mathrm{g} / \mathrm{ml}): 5.8 \mathrm{mg}(10 \mathrm{ml})$ of laronidase in $280 \mathrm{ml}$ of normal saline solution (SS). Solution C ( $2 \mu \mathrm{g} / \mathrm{ml}): 22.5 \mathrm{ml}$ of SS followed by $2.5 \mathrm{ml}$ of solution D. Solution B $(0.2 \mu \mathrm{g} / \mathrm{ml}): 22.5 \mathrm{ml}$ of SS followed by $2.5 \mathrm{ml}$ of solution C. Solution A $(0.02 \mu \mathrm{g} / \mathrm{ml}): 22.5 \mathrm{ml}$ of SS followed by $2.5 \mathrm{ml}$ of solution $\mathrm{B}$.

intradermal test with a 1:10 dilution was positive with a $4 \times 4 \mathrm{~mm}$ wheal and a $10 \times 10 \mathrm{~mm}$ flare reaction compared to the negative control. A 12-step arylsulfatase B desensitisation protocol was performed, resembling a protocol previously reported by Begin et al. (table 2) [5]. While he was receiving the third dose of desensitisa- tion, he experienced urticaria again. The infusion was interrupted. Before desensitisation, the patient was premedicated with hydroxyzine $(0.5 \mathrm{mg} / \mathrm{kg})$ and methylprednisolone $(1 \mathrm{mg} / \mathrm{kg})$. Since then, he has been receiving arylsulfatase B ERT with desensitisation and premedication weekly without any reaction.

Case 3

A 17-month-old girl was diagnosed with MPS I when she was 10 months old and had been receiving laronidase ERT $(0.58 \mathrm{mg} /$ $\mathrm{kg}$ ) every 2 weeks. While she was receiving the third dose of ERT, she experienced generalised urticaria, lip-swelling, dyspnoea, tachypnoea and hypotension, $30 \mathrm{~min}$ after starting the procedure. The infusion was stopped; the patient was treated with adrenalin $(0.01 \mathrm{mg} / \mathrm{kg}$ intramuscularly), methylprednisolone $(1 \mathrm{mg} / \mathrm{kg}$ intravenously), diphenhydramine $(1 \mathrm{mg} / \mathrm{kg})$ and nebulised salbutamol, and was admitted to the intensive care unit. When she was evaluated at our allergy clinic, a skin prick test with undiluted laronidase was negative. However, an intradermal test with a 1:100 dilution was positive with a $4 \times 4 \mathrm{~mm}$ wheal and a $6 \times 6 \mathrm{~mm}$ flare reaction compared to the negative control. A 16-step laronidase desensitisation protocol was prepared for her (table 3). Due to the fact that the patient developed urticaria during desensitisation, she was premedicated with hydroxyzine $(0.5 \mathrm{mg} / \mathrm{kg})$ and methylprednisolone $(1 \mathrm{mg} / \mathrm{kg})$ before desensitisation. She has been receiving laronidase ERT every 2 weeks with desensitisation and premedication without any reaction since.

\section{Discussion}

ERT is important in reducing the morbidity and mortality rates in patients with lysosomal storage disorders. Reactions can be experienced during ERT that can be caused by either IgE-mediated or non-immunologic mechanisms. The majority of infusion-associated reactions are successfully treated by interrupting or slowing the rate of infusion and/or by the administration of antihistamines, antipyretics and/or corticosteroids $[4,7,8]$. However, when these measures fail to prevent hypersensitivity reactions, desensitisation with the culprit enzyme is indicated [9]. In the literature, a few patients have received ERT with desensitisation [3, 5-7, 10-12]. Here we reported three cases in which the patients had IgE-mediated hypersensitivity reactions and subsequently underwent desensitisation prior to each application of ERT, without further reactions. However, in 2 of the cases, cases 2 and 3, premedication prior to each desensitisation protocol was needed.

Alglucosidase alfa for Pompe disease, arylsulfatase B for MPS VI and laronidase for MPS I have been used for ERT and have changed the progression of the diseases [13-16]. Even when allergic reactions are experienced, it is absolutely necessary to continue ERT. Only a few previous reports provide information about patients who have 
been desensitised with the culprit enzyme. Our patients experienced reactions despite slowing the rate of infusion and the administration of premedication. The patients had positive intradermal skin tests with the culprit enzymes. Desensitisation was successfully performed for all 3 patients without any reaction. They have since been undergoing ERT after desensitisation with premedication without any problem.

Generally, it is preferred to use desensitisation protocols after they have been successfully used on at least 10 patients; however, there are only a few patients who have had ERT with desensitisation. Thus, we planned our protocols using the general rules that are suggested by the recent 'EAACI Consensus Statement on Rapid Desensitisation for Drug Hypersensitivity' [17]. We also considered the few protocols that were reported in the literature.

Infusion reactions with ERT have been reported in $14 \%$ of patients with Pompe disease. To our knowledge, 3 patients in the literature have been desensitised with alglucosidase alfa. The first was an adult who experienced anaphylaxis during enzyme infusion, and her intradermal test was positive at a 1:100 dilution. She was desensitised with a 12-step protocol that lasted 12-14 h [6]. A 15-month-old girl also experienced anaphylaxis during treatment and was desensitised over 18 weeks, by doubling the dose of solution every week [18]. A 7-month-old girl who experienced anaphylaxis during treatment had a positive intradermal test with a 1:1,000 dilution. She was desensitised with a 14-step protocol using solutions of 6 different concentrations [19]. Our patient (case 1) experienced urticaria during infusion, and her intradermal test was positive with a 1:100 dilution. We used a 14-step protocol, which lasted $6 \mathrm{~h}$, using solutions of 5 increasing concentrations, resembling the protocol used by Karagöl et al. [19].
In the literature, there is only 1 patient who was desensitised with arylsulfatase B. A 10-year-old patient with MPS VI was reported to have urticaria concomitant with severe conjunctivitis and lip angioedema. The patient had a positive intradermal skin test with a 1:100 dilution and was desensitised with a 16-step protocol, which lasted for $5 \mathrm{~h}$ [5]. Our patient (case 2) had generalised urticaria without systemic symptoms and had a positive intradermal test with a 1:10 dilution. Because he did not have systemic symptoms, we wanted to use a shorter protocol. We desensitised this patient with a 12 -step protocol that lasted for $3 \mathrm{~h}$.

Infusion reactions with laronidase have been reported in $16 \%$ of patients with MPS. In the literature, there is only 1 patient who was desensitised with laronidase. An 11-year-old girl with MPS I was desensitised because she had generalised urticaria during a laronidase infusion. Skin tests were not performed. The desensitisation protocol comprised 12 steps [3]. Our patient (case 3) was too young and had previously experienced an anaphylactic reaction during infusion, so we applied the procedure in 16 steps, using a slow increase of the concentrations. The procedure was completed within $7 \mathrm{~h}$.

To conclude, the discontinuation of ERT due to adverse drug reactions is a significant loss for patients with metabolic disorders. When patients with these disorders experience IgE-mediated allergic reactions with enzyme replacement, an allergic evaluation and skin tests should be performed, and continuation of the treatment with desensitisation must be considered.

\section{Disclosure Statement}

There is no financial disclosure and there is no conflict of interest.

\section{References}

1 Champion MP: An approach to the diagnosis of inherited metabolic disease. Arch Dis Child Educ Pract Ed 2010;95:40-46.

2 Lindor NM, Karnes PS: Initial assessment of infants and children with suspected inborn errors of metabolism. Mayo Clin Proc 1995; 70:987-988

3 Ensina LF, Aranda CS, de Lacerda AE, Camelo-Nunes I, Sole D, Martins AM, Castells M: Laronidase hypersensitivity and desensitization in type I mucopolysaccharidosis: a case report. Pediatr Allergy Immunol 2014;25: 498-499.
4 Kim KH, Decker C, Burton BK: Successful management of difficult infusion-associated reactions in a young patient with mucopolysaccharidosis type VI receiving recombinant human arylsulfatase B (galsulfase [Naglazyme]). Pediatrics 2008;121:e714-e717.

5 Begin P, Chapdelaine H, Lemyre E, Paradis L, Des Roches A: Successful desensitization in a type VI mucopolysaccharidosis patient with probable IgE-mediated allergy to galsulfase [Naglazyme]. Ann Allergy Asthma Immunol 2013;110:55-56.
6 Lipinski SE, Lipinski MJ, Burnette A, PlattsMills TA, Wilson WG: Desensitization of an adult patient with Pompe disease and a history of anaphylaxis to alglucosidase alfa. Mol Genet Metab 2009;98:319-321.

7 El-Gharbawy AH, Mackey J, DeArmey S, Westby G, Grinnell SG, Malovrh P, Conway R, Kishnani PS: An individually, modified approach to desensitize infants and young children with Pompe disease, and significant reactions to alglucosidase alfa infusions. Mol Genet Metab 2011;104:118-122.
Hypersensitivity and Desensitisation with Recombinant Enzymes
Int Arch Allergy Immunol 2016;169:198-202 DOI: $10.1159 / 000446154$ 
8 Burton BK, Whiteman DA; Investigators HOS: Incidence and timing of infusion-related reactions in patients with mucopolysaccharidosis type II (Hunter syndrome) on idursulfase therapy in the real-world setting: a perspective from the Hunter Outcome Survey (HOS). Mol Genet Metab 2011;103:113120.

9 Castells M: Rapid desensitization for hypersensitivity reactions to medications. Immunol Allergy Clin North Am 2009;29:585-606.

10 Talreja N, Butt A, Valle RL, Fox RW, Lockey RF: Successful desensitization to agalsidase beta after anaphylaxis. Ann Allergy Asthma Immunol 2014;112:71-72.

11 Erdogdu D, Gelincik A, Canbaz B, Colakoglu B, Buyukozturk S, Tanakol R: Successful desensitization to imiglucerase of an adult patient diagnosed with type I Gaucher disease. Int Arch Allergy Immunol 2013;160:215-217.

12 Serrano CD, Gomez JF: Successful desensitization to idursulfase in a patient with type II mucopolysaccharidosis (Hunter syndrome). J Investig Allergol Clin Immunol 2011;21:571572.
13 Van der Ploeg AT, Reuser AJ: Pompe's disease. Lancet 2008;372:1342-1353.

14 Montagnese F, Barca E, Musumeci O, Mondello S, Migliorato A, Ciranni A, Rodolico C, De Filippi P, Danesino C, Toscano A: Clinical and molecular aspects of 30 patients with lateonset Pompe disease (LOPD): unusual features and response to treatment. J Neurol 2015;262:968-978.

15 Herskhovitz E, Young E, Rainer J, Hall CM, Lidchi V, Chong K, Vellodi A: Bone marrow transplantation for Maroteaux-Lamy syndrome (MPS VI): long-term follow-up. J Inherit Metab Dis 1999;22:50-62.

16 Giugliani R, Federhen A, Rojas MV, Vieira T, Artigalas O, Pinto LL, Azevedo AC, Acosta A, Bonfim C, Lourenço CM, Kim CA, Horovitz D, Bonfim D, Norato D, Marinho D, Palhares D, Santos ES, Ribeiro E, Valadares E, Guarany F, de Lucca GR, Pimentel H, de Souza IN, Correa J Sr, Fraga JC, Goes JE, Cabral JM, Simionato J, Llerena J Jr, Jardim L, Giuliani L, da Silva LC, Santos ML, Moreira MA, Kerstenetzky $M$, Ribeiro $M$, Ruas $N$, Barrios $P$, Aranda P, Honjo R, Boy R, Costa R, Souza C, Alcantara FF, Avilla SG, Fagondes S, Martins AM: Mucopolysaccharidosis I, II, and VI: brief review and guidelines for treatment. Genet Mol Biol 2010;33:589-604.
17 Cernadas JR, Brockow K, Romano A, Aberer W, Torres MJ, Bircher A, Campi P, Sanz ML, Castells M, Demoly P, Pichler WJ; European Network of Drug Allergy and the EAACI Interest Group on Drug Hypersensitivity: General considerations on rapid desensitization for drug hypersensitivity - a consensus statement. Allergy 2010;65:1357-1366.

18 Baruteau J, Broomfield A, Crook V, Finnegan N, Harvey K, Burke D, Burch M, Shepherd G, Vellodi A: Successful desensitisation in a patient with CRIM-positive infantile-onset Pompe disease. JIMD Rep 2014;12:99-102.

19 Karagöl IH, Bakirtas A, Yilmaz O, Topal E, Kucukcongar A, Ezgu FS, Demirsoy MS, Turktas I: Desensitisation of the youngest patient with Pompe disease in response to alglucosidase alfa. Allergol Immunopathol (Madr) 2014;42:372-375. 